Journal of Oral Rehabilitation, 1976, Volume 3, pages 217-226

\title{
Characterization of porosity of isostatically pressed and sintered nickel-base powdered metal*
}

\author{
R. A. FUYS, JR, R. G. CRAIG and K. ASGAR The University \\ of Michigan School of Dentistry, Ann Arbor, Michigan, U.S.A.
}

\section{Summary}

Characterization of the pore structure of compacted and sintered parts made from a nickel-base powder was accomplished using the mercury porosimetry method. The theoretical density values for the sintered specimens varied from 56.3 to $96.7 \%$ which corresponds to a porosity of 43.7 to $3.3 \%$. A maximum interconnecting median pore diameter of $21 \mu \mathrm{m}$ resulted from a $-80 /+200$ mesh powder compacted at $138 \mathrm{MN} /$ $\mathrm{m}^{2}$ and sintered for $2 \mathrm{~h}$ at $1250^{\circ} \mathrm{C}$. Photomicrographs of the same sample showed that it had a maximum pore diameter of $200 \mu \mathrm{m}$. The interconnected pore volume decreased with decreasing particle size of the powder, increasing compaction pressure, and increasing sintering temperature. Mechanical properties of tensile strength, yield strength, elastic modulus and percentage elongation were correlated with the pore structure. Proper selection of particle size, compaction pressure, sintering times and sintering temperatures should permit parts with controlled porosity characteristics to be produced that possess adequate mechanical properties for application as implants.

\section{Introduction}

The physical and mechanical properties of samples of a nickel-base alloy fabricated by powder metallurgy were reported by Fuys, Craig \& Asgar (1976). The properties of a number of these samples indicated that the powder metallurgy method is particularly suited to the fabrication of metal parts for implants, a conclusion substantiated by Hirschhorn \& Reynolds (1968).

Klawitter (1970) investigated the effect of pore size on the type and extent of tissue ingrowth into porous ceramic materials. He found that interconnecting pores of 5-15 $\mu \mathrm{m}$ were necessary for the ingrowth of fibrous tissue and that pores greater than $100 \mu \mathrm{m}$ were needed for the ingrowth of mineralized bone. It is apparent, therefore, that the characterization of the pore structure of the nickel-base samples prepared by powder metallurgy is of particular importance.

The determination of the penetration of mercury into porous solids has become a highly useful method for characterizing porous materials. Orr (1969/1970), Rootare

\footnotetext{
* Taken from a portion of a dissertation in partial fulfilment of the requirements for the Ph.D. degree, University of Michigan, Horace H. Rackham School of Graduate Studies, 1971.

Correspondence: Dr Robert G. Craig, Department of Dental Materials, School of Dentistry, University of Michigan, Ann Arbor, Michigan 48104, U.S.A.
} 
(1970), Dullien \& Batra (1970) and Rootare \& Nyce (1971) have presented thorough reviews of this method now referred to as mercury porosimetry. The method depends on the high contact angle of mercury against most solids and thus mercury does not automatically enter the pores at normal pressure but can be forced into the pores by increasing the pressure. The technique measures simultaneously the pressure and volume of mercury that has penetrated the sample up to that pressure. By making certain assumptions about the geometry of the pores, plots of cumulative pore volume versus pore diameter are obtained.

The object of the present investigation was to characterize the porosity of powder metallurgy samples of a nickel-base alloy as a function of particle size of the powder, compaction conditions and sintering parameters, using mercury porosimetry. It was also the purpose to correlate the porosity of the samples with their mechanical properties.

\section{Materials and methods}

The same powders, isostatic pressing techniques, and sintering conditions were used as those described by Fuys et al. (1976).

Two mercury porosimeters, 103 and $414 \mathrm{MN} / \mathrm{m}^{2}$ types, * were used to determine the interconnected porosity and the cumulative pore volumes as a function of pore diameter of the various compacted and sintered powders. With the $103 \mathrm{MN} / \mathrm{m}^{2}$ type the pressure is read directly and the intrusion of mercury is determined by direct reading of the mercury level in the penetrometer. The penetrometer is a glass container with a capillary tube; the sample is placed in the container and the penetrometer filled with mercury. The penetrometer is placed in a pressure vessel with a glass viewer and the change in level of the mercury in the capillary tube is determined visually as a function of pressure. In the $414 \mathrm{MN} / \mathrm{m}^{2}$ porosimeter the mercury level in the penetrometer is measured by determining the capacitance between the mercury in the capillary and an external metal shield around the glass capillary stem and the capacitance is directly related to the change in the volume of mercury in the stem.

\section{Results}

Interconnected Pore Volume-The interconnected pore volume for the nonsintered (green) and sintered compacts made from powders of different particle size are shown in Fig. 1. Compaction pressures of 138,276 and $414 \mathrm{MN} / \mathrm{m}^{2}$ and sintering temperatures of 1150,1200 and $1250^{\circ} \mathrm{C}$ were used. The sintering was conducted in vacuum at $10^{-6}$ Torr. The interconnected pore volume for sintered samples ranged from $0.09 \mathrm{~cm}^{3} / \mathrm{g}$ for the $-80 /+200$ mesh powder compacted at $138 \mathrm{MN} / \mathrm{m}^{2}$ and sintered at $1150^{\circ} \mathrm{C}$ to $0.002 \mathrm{~cm}^{3} / \mathrm{g}$ for samples from -325 mesh powder compacted at $414 \mathrm{MN} / \mathrm{m}^{2}$ and sintered at $1250^{\circ} \mathrm{C}$. The interconnected pore volumes for nonsintered compacts varied from $0.10 \mathrm{~cm}^{3} / \mathrm{g}$ for samples made from $-80 /+200$ mesh powder compacted at $138 \mathrm{MN} / \mathrm{m}^{2}$ to $0.04 \mathrm{~cm}^{3} / \mathrm{g}$ for samples fabricated from -325 mesh powder compacted at $414 \mathrm{MNm}^{2}$.

The following trends in interconnected pore volume were found. The interconnected pore volume decreased with: decreasing particle size at each sintering temperature; increasing compaction pressure at each sintering temperature; and increasing sintering

\footnotetext{
* $15000 \mathrm{psi}\left(103 \mathrm{MN} / \mathrm{m}^{2}\right)$ and $60000 \mathrm{psi}\left(414 \mathrm{MN} / \mathrm{m}^{2}\right)$ AMINCO Porosimeters, American
} Instrument Co., Silver Spring, Md. 


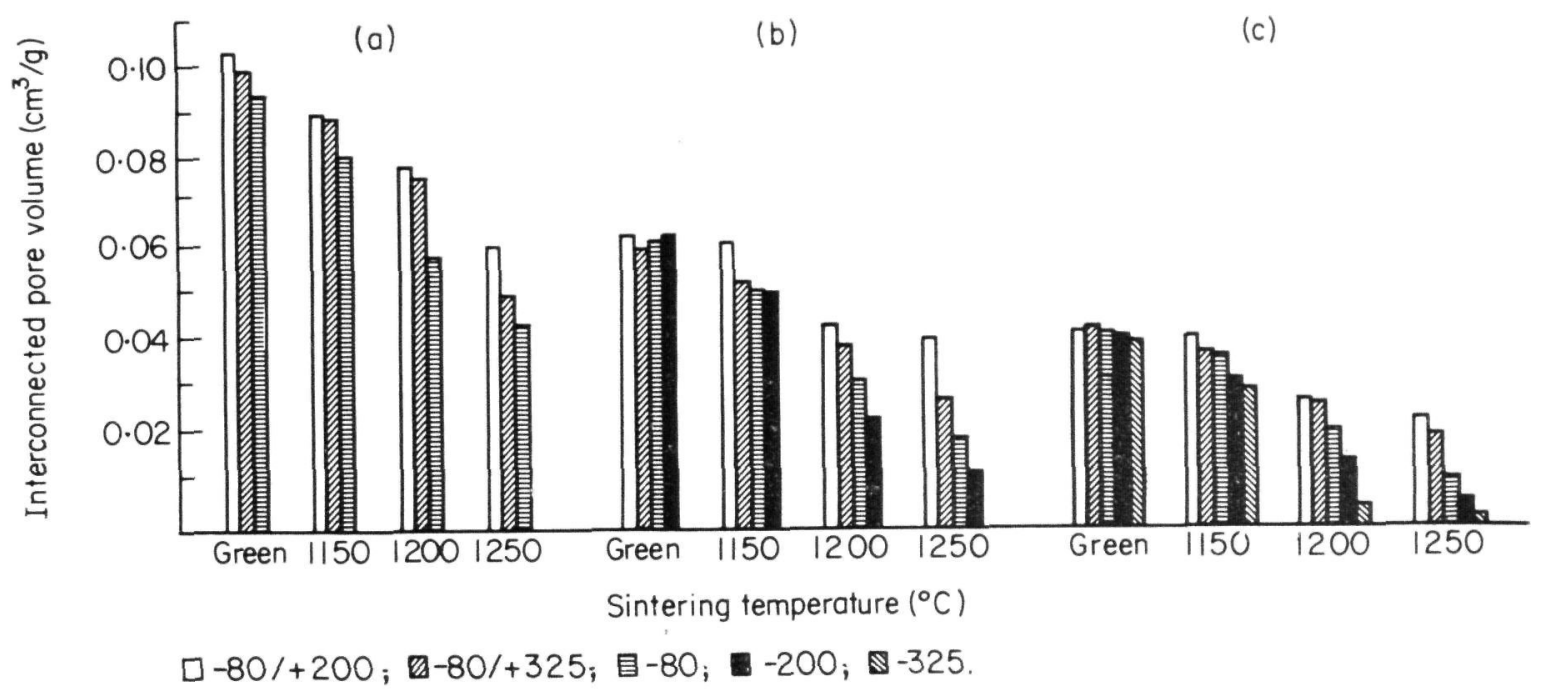

Fig. 1. Interconnected pore volume of samples made from powders of various particle sizes as a function of compaction pressure and sintering temperature. Compaction pressure: $138 \mathrm{MN} / \mathrm{m}^{2}$ (a), $276 \mathrm{MN} / \mathrm{m}^{2}$ (b) and $414 \mathrm{MN} / \mathrm{m}^{2}$ (c).

temperature at each compaction pressure. For nonsintered samples the interconnected pore volume decreased with increasing compaction pressure for each particle size level.

Median Pore Diameters-The median pore diameters as a function of fabrication parameters are shown in Fig. 2. At the three compaction pressure levels the median pore diameters decreased with decreasing particle size at each sintering temperature. At $138 \mathrm{MN} / \mathrm{m}^{2}$ compaction level the median pore diameter for each powder particle size increased with increasing sintering temperature. At the $276 \mathrm{MN} / \mathrm{m}^{2}$ level the median pore diameter for samples from $-80 /+200$ and $-80 /+325$ mesh powders increased at all three sintering temperatures. Samples from -80 mesh powder increased in pore diameter from 1150 to $1200^{\circ} \mathrm{C}$ but decreased at $1250^{\circ} \mathrm{C}$. Samples from -200 mesh powder sintered at $1150^{\circ} \mathrm{C}$ exhibited an increase in median pore diameter compared to the unsintered (green) sample; sintering at 1200 and $1250^{\circ} \mathrm{C}$ resulted in decreased median pore diameters. At the $276 \mathrm{MN} / \mathrm{m}^{2}$ level the median pore diameters

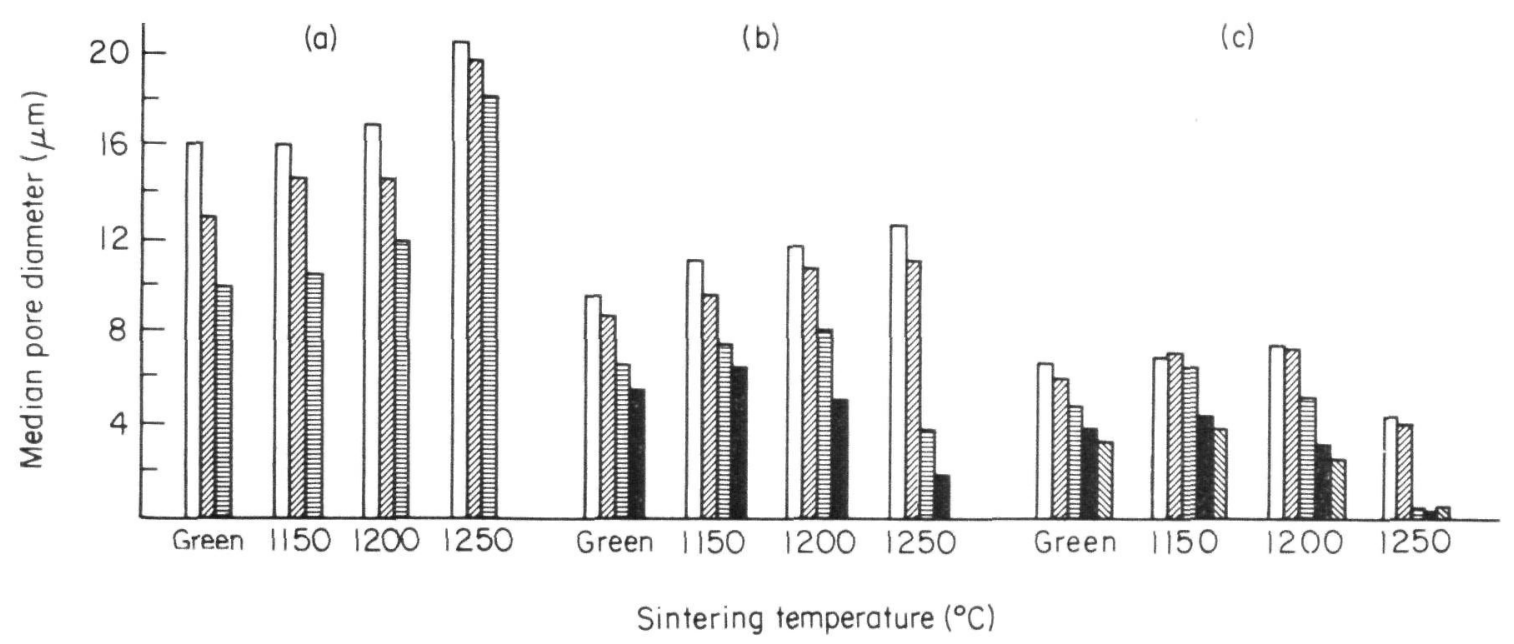

$\square-80 /+200 ;$ 四-80/+325; 目-80; $-200 ;-325$.

Fig. 2. Median pore diameter of samples made from powders of various particle sizes as a function of compaction pressure and sintering temperature. Compaction pressure: $138 \mathrm{MN} / \mathrm{m}^{2}$ (a), $276 \mathrm{MN} / \mathrm{m}^{2}$ (b) and $414 \mathrm{MN} / \mathrm{m}^{2}$ (c). 
ranged from $13.7 \mu \mathrm{m}$ for the $-80 /+200$ mesh powder to $1.8 \mu \mathrm{m}$ for the -200 mesh powder.

Samples compacted at $414 \mathrm{MN} / \mathrm{m}^{2}$ from $-80 /+200$ and $-80 /+325$ mesh powders sintered at 1150 and $1200^{\circ} \mathrm{C}$ showed an increase in median pore diameter; sintering these compacts at $1250^{\circ} \mathrm{C}$ resulted in a decrease in median pore diameter. Sintering $-80,-200$ and -325 mesh compacts at 1150,1200 and $1250^{\circ} \mathrm{C}$ resulted in decreases in median pore diameter. Median pore diameters of samples prepared at $414 \mathrm{MN} / \mathrm{m}^{2}$ ranged from $7 \cdot 5 \mu \mathrm{m}$ for $-80 /+200$ mesh powder sintered at $1200^{\circ} \mathrm{C}$ to $0.3 \mu \mathrm{m}$ for -200 mesh sintered at $1250^{\circ} \mathrm{C}$.

The highest median pore diameter was $20.5 \mu \mathrm{m}$ for $-80 /+200$ mesh powder compacted at $138 \mathrm{MN} / \mathrm{m}^{2}$ and sintered at $1250^{\circ} \mathrm{C}$ and the lowest pore diameter was $0.3 \mu \mathrm{m}$ for -200 mesh powder compacted at $414 \mathrm{MN} / \mathrm{m}^{2}$ and sintered at $1250^{\circ} \mathrm{C}$.

Pore Size Distributions-The cumulative pore volume versus pore diameter for compacts of the various powders prepared at 138, 276 and $414 \mathrm{MN} / \mathrm{m}^{2}$ are shown at the top, middle and bottom of Fig. 3, respectively. The shapes of the curves are similar indicating a rather narrow distribution of pore sizes by the sharp increase in each curve. The pore diameters and interconnected pore volumes decreased with increasing com-

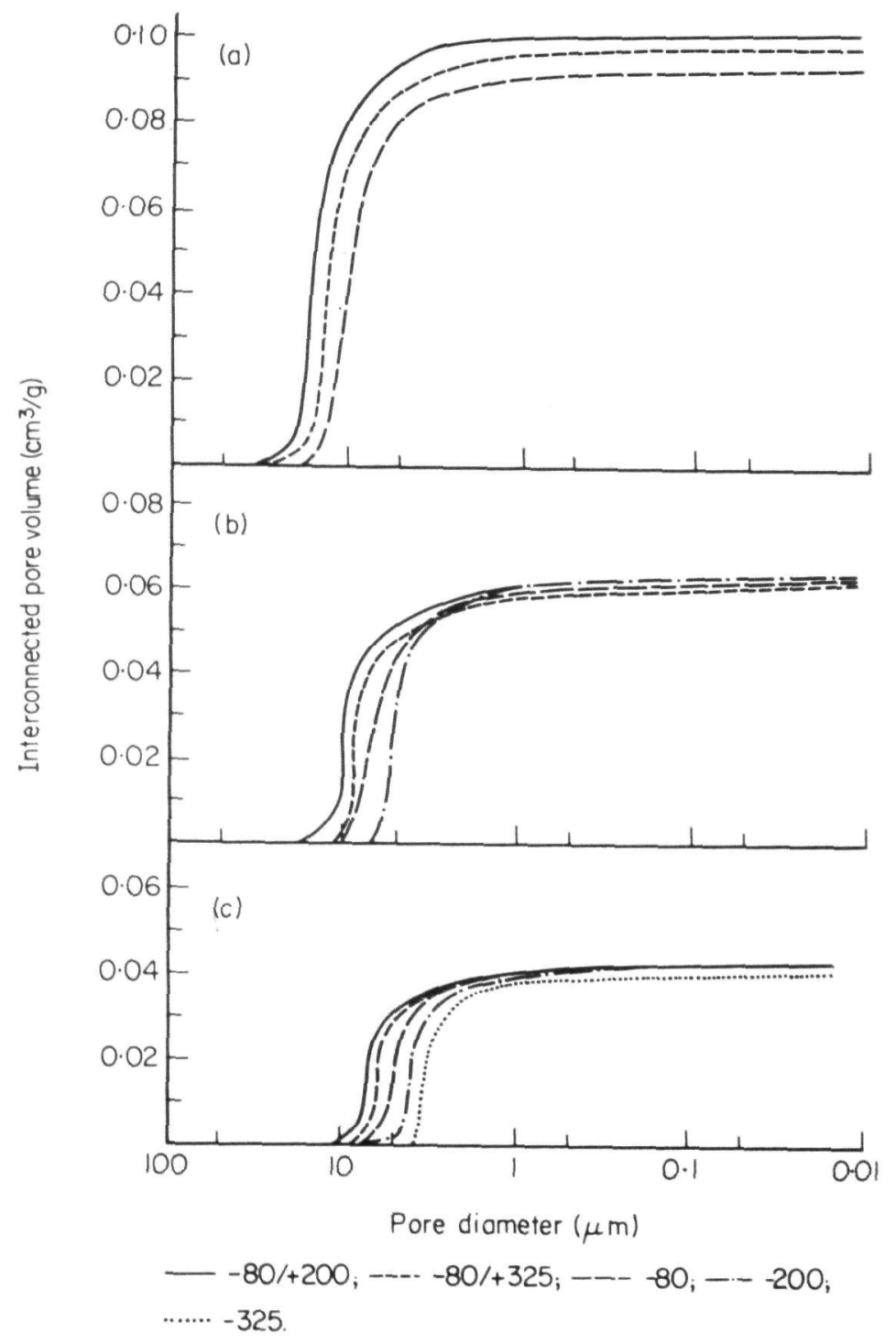

Fig. 3. Cumulative pore volumes as a function of pore diameter of compacts prepared at $138 \mathrm{MN} / \mathrm{m}^{2}$ (a), $276 \mathrm{MN} / \mathrm{m}^{2}$ (b) and $414 \mathrm{MN} / \mathrm{m}^{2}$ from powders of various particle sizes. 


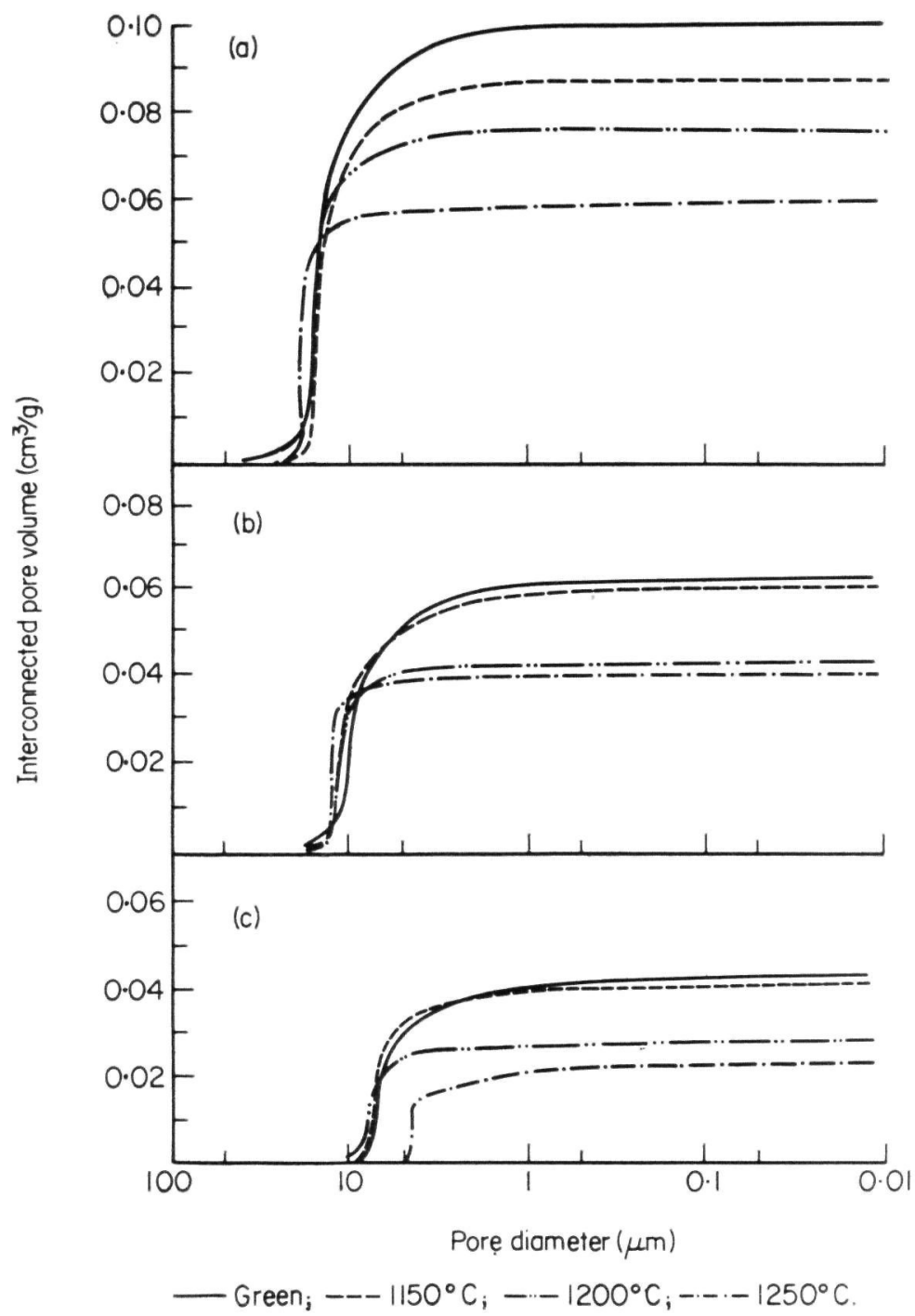

Fig. 4. Cumulative pore volumes as a function of pore diameter of compacts prepared at $138 \mathrm{MN} / \mathrm{m}^{2}$ (a), $276 \mathrm{MN} / \mathrm{m}^{2}$ (b) and $414 \mathrm{MN} / \mathrm{m}^{2}$ (c) from $-80 /+200$ mesh powder at sintering temperatures 1150,1200 and $1250^{\circ} \mathrm{C}$.

paction pressure. As an example, for the $-80 /+200$ mesh powder compacted at the three pressures the pore volumes were $0.103,0.064$ and $0.043 \mathrm{~cm}^{3} / \mathrm{g}$ and the median pore diameters were $16 \cdot 1,9 \cdot 6$ and $6 \cdot 6 \mu \mathrm{m}$, respectively.

The pore volume versus pore diameter curves for the sintered compacts from $-80 /+200$ mesh powder are shown in Fig. 4. The pore volumes decreased with increasing sintering temperature. At $138 \mathrm{MN} / \mathrm{m}^{2}$, sintering at $1250^{\circ} \mathrm{C}$ resulted in a pore diameter increase, at $276 \mathrm{MN} / \mathrm{m}^{2}$ the pore diameter increased with increasing sintering temperatures, and at $414 \mathrm{MN} / \mathrm{m}^{2}$ the pore diameter increased slightly at 1150 and $1200^{\circ} \mathrm{C}$ but decreased at $1250^{\circ} \mathrm{C}$.

Similar effects of sintering on pore volume and diameter were observed for the other powders with smaller particle size powders yielding samples with smaller pore volumes and pore diameters. For the coarsest powder, $-80 /+200$ mesh, the pore volume was $0.090 \mathrm{~cm}^{3} / \mathrm{g}$ (compacted at $138 \mathrm{MN} / \mathrm{m}^{2}$ and sintered at $1150^{\circ} \mathrm{C}$ ) and for the finest powder, -325 mesh, the pore volume was $0.002 \mathrm{~cm}^{3} / \mathrm{g}$ (compacted at $414 \mathrm{MN} / \mathrm{m}^{2}$ and sintered at $1250^{\circ} \mathrm{C}$ ). The median pore diameters varied from $20.5 \mu \mathrm{m}$ for the $-80 /+200$ mesh powder to $3 \cdot 3 \mu \mathrm{m}$ for the -325 mesh powder. Additional curves for the various conditions have been described by Fuys (1971). 


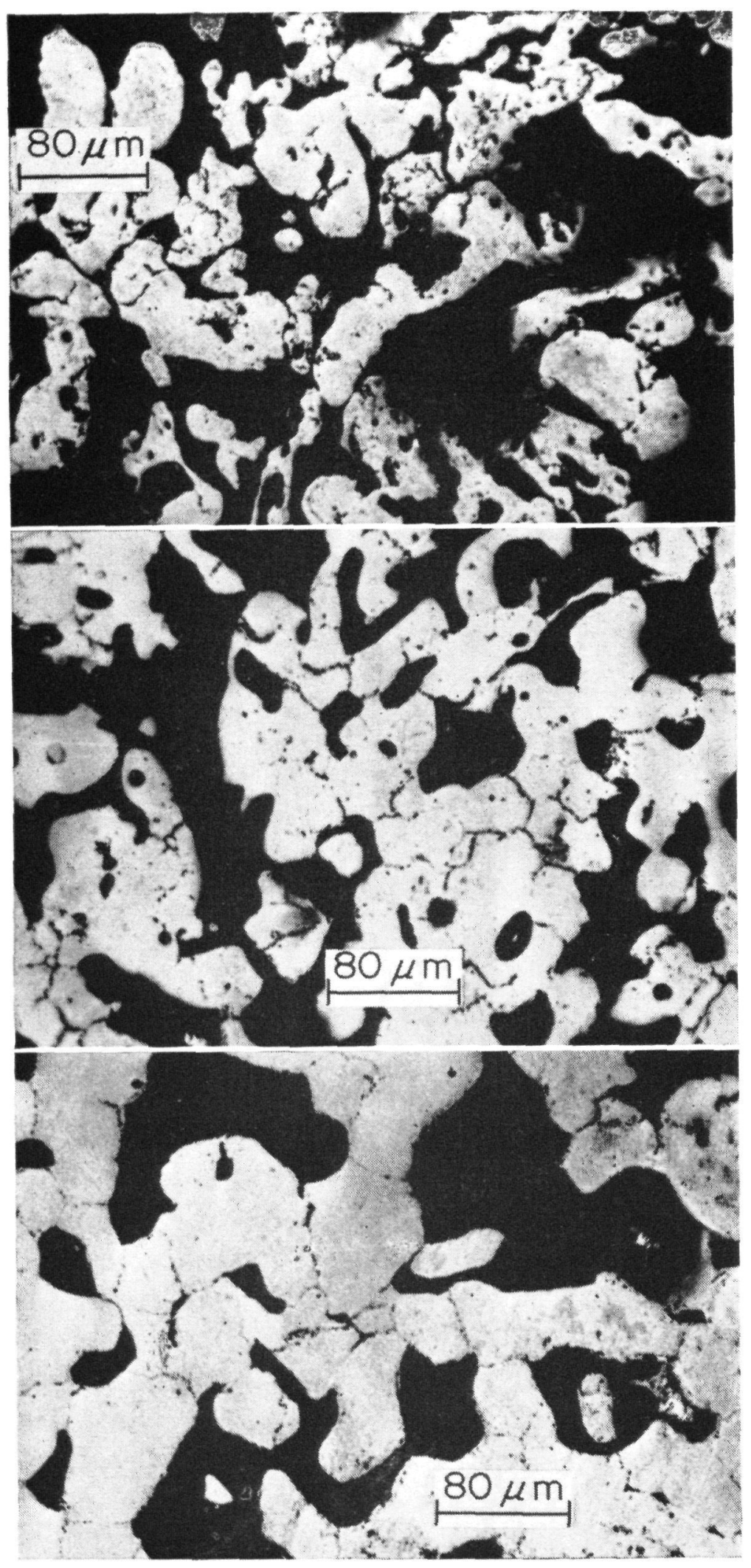

Fig. 5. Photomicrographs of sections of samples of $-80 /+200$ mesh powder compacted at $138 \mathrm{MN} / \mathrm{m}^{2}$ and sintered at $1150^{\circ} \mathrm{C}$ (top), $1200^{\circ} \mathrm{C}$ (middle), and $1250^{\circ} \mathrm{C}$ (bottom).

Microstructure-photomicrographs of compacts made from $-80 /+200$ mesh powder at $138 \mathrm{MN} / \mathrm{m}^{2}$ and sintered at 1150,1200 and $1250^{\circ} \mathrm{C}$ are shown in Fig. 5 top, middle and bottom, respectively. The largest pore sizes and grains were obtained with samples prepared at $1250^{\circ} \mathrm{C}$, and it is apparent that the pore volume of the sample prepared at $1150^{\circ} \mathrm{C}$ was the highest followed by samples at 1200 and $1250^{\circ} \mathrm{C}$. 


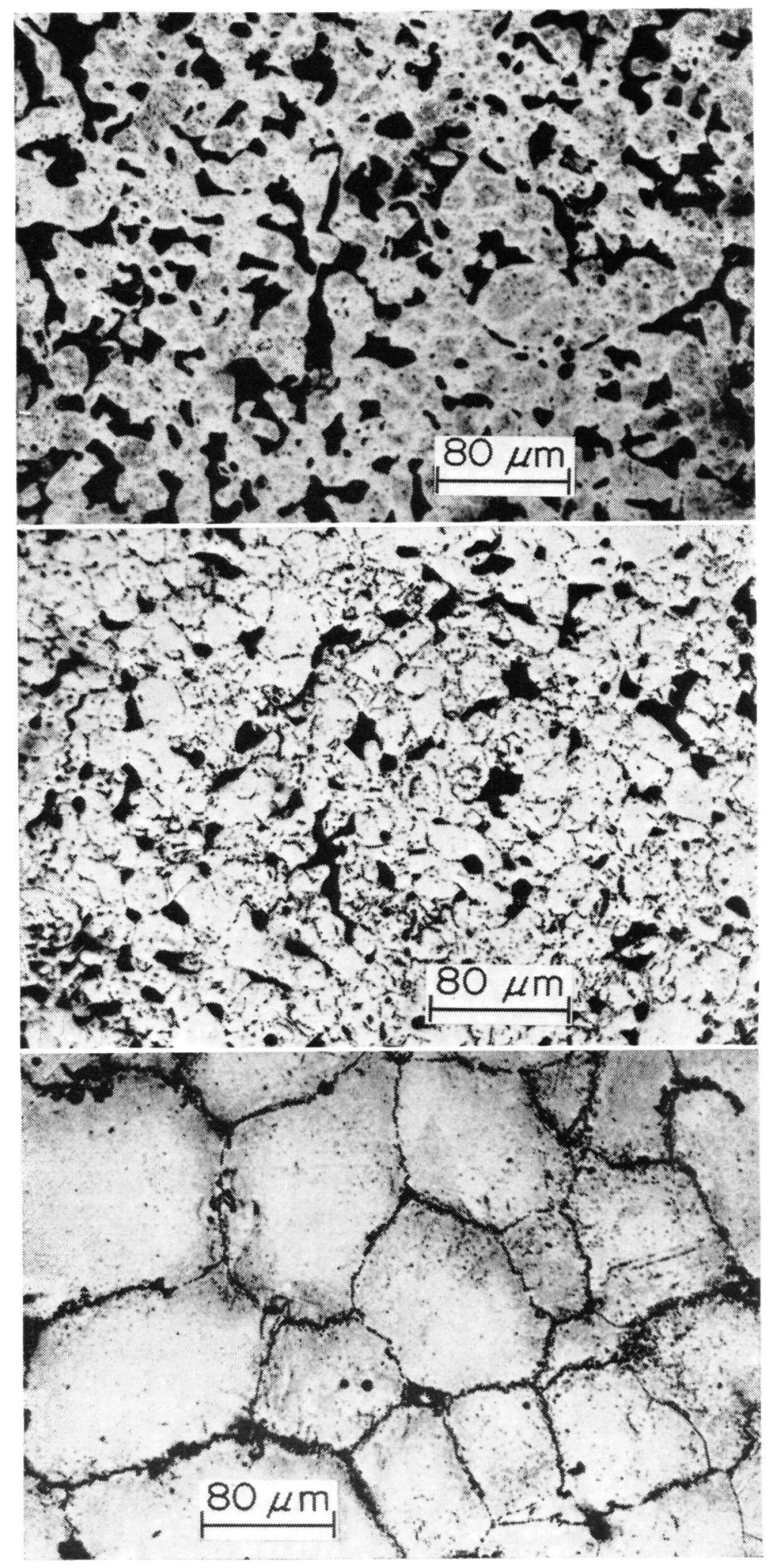

Fig. 6. Photomicrographs of section of samples of -325 mesh powder compacted at $414 \mathrm{MN} / \mathrm{m}^{2}$ and sintered at $1150^{\circ} \mathrm{C}$ (top), $1200^{\circ} \mathrm{C}$ (middle) and $1250^{\circ} \mathrm{C}$ (bottom).

The photomicrographs in Fig. 5 indicate that pores as large as $150-200 \mu \mathrm{m}$ were obtained, although the mercury porosimetry data indicated that the median pore diameter of the interconnections between the pores was $20.5 \mu \mathrm{m}$.

The photomicrographs of samples of -325 mesh powder compacted at $414 \mathrm{MN} / \mathrm{m}^{2}$ and sintered at 1150,1200 and $1250^{\circ} \mathrm{C}$ are shown in Fig. 6 (top, middle and bottom). The most pronounced change in structure occurred for the sample sintered at $1250^{\circ} \mathrm{C}$. 
The homogeneous grain size and lack of segregation are typical of the high density powder metallurgy parts.

\section{Discussion}

The particle size of the powder, the compaction pressure, and the sintering temperature control the interconnected pore volume, median pore diameter and pore size distribution. In general, increasing the compaction pressure, decreasing the particle size of the powder and increasing the sintering temperature resulted in decreased interconnected porosity. The effects of these factors on the median pore diameter was not so straightforward. At lower compaction pressures and larger particle sizes increased sintering temperatures generally resulted in larger median pore diameters, while at higher compaction pressures and smaller particle sizes increased sintering temperatures resulted in decreased median pore diameters. These effects probably result from the melting of the junctions during sintering of the rather loosely compacted samples compared with the highly dense compaction.

The irregular shapes of the pores are emphasized by the photomicrographs and thus pores contain constrictions, or necks, as they travel from the surface of the sample to the interior. The pressure required to fill the pores is dominated by the constrictions since if a constriction is present in a pore it will not continue filing until the pressure is high enough to force the mercury through the constriction. The pore distributions and median pore diameters are therefore biased toward the smaller pores as a result of these constrictions and in reality much larger pores exist in the samples than indicated by mercury porosimetry.

The fact that the mercury porosimetry data indicate that smaller than actual pores exist is supported by the photomicrographs in Fig. 5 of the compacted and sintered samples prepared from the $-80 /+200$ mesh powder compacted at $138 \mathrm{MN} / \mathrm{m}^{2}$. Median pore diameters of about 16,17 and $20 \cdot 5 \mu \mathrm{m}$ were obtained by mercury porosimetry whereas the photomicrographs indicate that portions of the pores are greater than $200 \mu \mathrm{m}$ even recognizing that some of the pores may be sectioned through the long dimension. This effect is also apparent in Fig. 6 which indicate that for the -325 mesh powder compacted at $414 \mathrm{MN} / \mathrm{m}^{2}$ and sintered at 1150 and $1200^{\circ} \mathrm{C}$ that the pore diameters are about $20 \mu \mathrm{m}$ whereas the mercury porosimetry data gave values of about $4 \mu \mathrm{m}$.

It appears reasonable that the pore diameters from mercury porosimetry data are a better indication of whether tissue will grow to any depth in the pores since the constrictions in the pores will probably be the limiting factor.

The mechanical properties of the compacted and sintered samples reported by Fuys et al. (1976) can be related to the interconnected porosity. The tensile and yield strengths as well as the elastic modulus values had a linear relationship to the percent interconnected porosity. The tensile strength increased from 207 to $966 \mathrm{MN} / \mathrm{m}^{2}$ as the interconnected porosity decreased from 40 to $3 \%$. Increases in $0.1 \%$ offset yield strength were from 138 to $724 \mathrm{MN} / \mathrm{m}^{2}$ and for the elastic modulus were from 41,380 to $193,100 \mathrm{MN} / \mathrm{m}^{2}$.

The effect of interconnected porosity on elongation is shown in Fig. 7. Marked increases in the percent elongation occurred when the interconnected porosity decreased below $5-15 \%$. The elongation of samples sintered at 1150 and $1200^{\circ} \mathrm{C}$ were similar while those prepared at $1250^{\circ} \mathrm{C}$ were significantly different. These data are of particular interest since they show that considerable porosity may exist with 


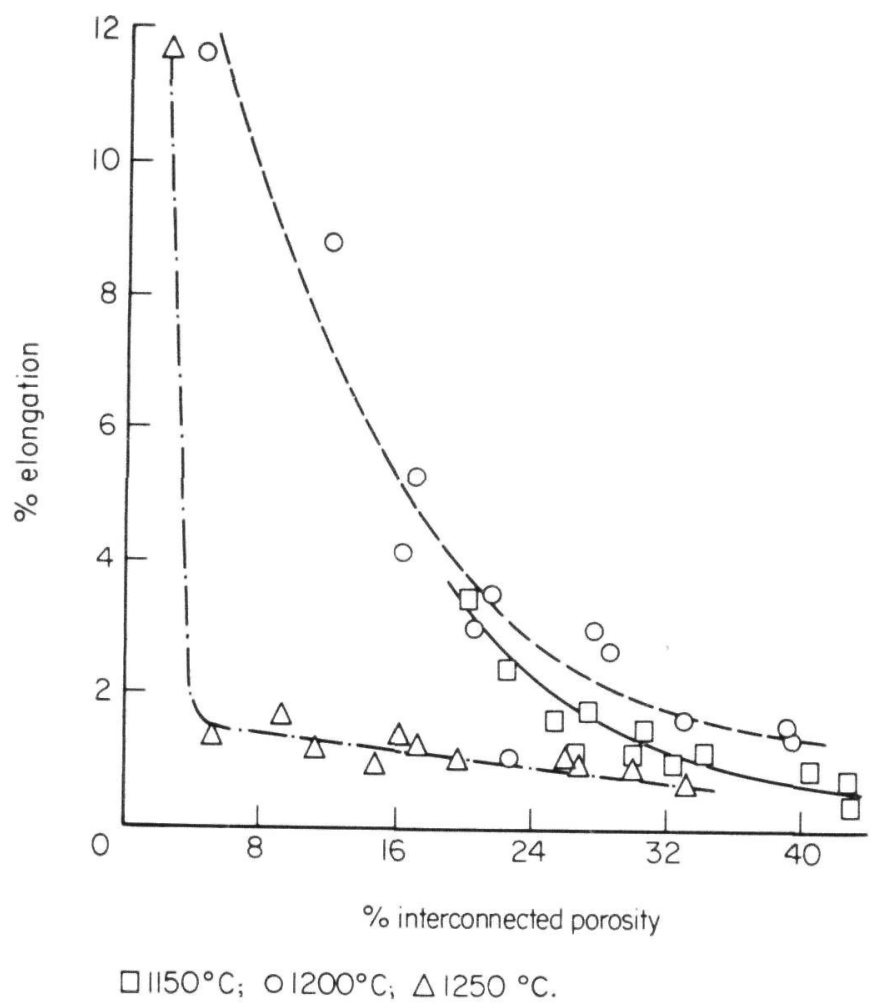

Fig. 7. Percentage elongation versus percentage interconnected porosity for compacts sintered at 1150,1200 and $1250^{\circ} \mathrm{C}$.

adequate mechanical properties. For example, a sample could have $8 \%$ porosity and have a tensile strength, $0 \cdot 1 \%$ offset yield strength, and modulus of elasticity of 759 , 621 and $158,620 \mathrm{MN} / \mathrm{m}^{2}$, respectively.

In summary, the characterization of powder metallurgy samples showed that by controlling the particle size of the powder, the compaction pressure, and the sintering that samples with a controlled amount of porosity could be obtained. The mechanical properties of some of the samples should be adequate to be used in stress-bearing areas of the mouth. Controlling the variables should allow the preparation of samples with controlled porosity and pore diameters.

\section{Acknowledgments}

This study was supported in part by Training Grant DE-00181 from the National Institute of Dental Research, Bethesda, Md.

\section{References}

Dullien, F.A. \& Batra, V.K. (1970) Determination of the structure of porous media. Ind. Eng. Chem., 62, 25.

FUYS, R.A., JR (1971) Isostatic pressing of nickel base powder metallurgy parts for potential bioengineering applications. Doctoral Dissertation, Ann Arbor, University Michigan.

Fuys, R.A., JR, Craig, R.G. \& Asgar, K. (1976) Physical properties of a nickel-base alloy prepared by isostatic pressing and sintering of the powdered metal. Journal of Oral Rehabilitation, 3, 151.

HirschHorn, J.S. \& Reynolds, J.T. (1968) Powder metallurgy fabrication of cobalt alloy surgical implant materials. In: Research in Dental and Medical Materials (Ed. by E. Korostoff), pp. 137-150. Plenum Press, New York.

KlawitTER, J.J., JR (1970) A basic investigation of bone growth with porous ceramic material. Doctoral dissertation, Clemson University, Engineering School.

OrR, C. (1969/1970) Application of mercury penetration to materials analysis. Powder Technology, 3, 117. 
226 R. A. Fuys, Jr, R. G. Craig and K. Asgar

Rootare, H.M. (1970) A review of mercury porosimetry. In: Perspectives in Powder Metallurgy (Ed. by H.H.Hausner, K.H.Roll and P.K.Johnson), p. 225. Plenum Press, New York.

Rootare, H.M. \& NyCE, A.C. (1971) Application mercury penetration to materials analysis. Powder Technology, 7, 3 .

Manuscript accepted 21 April 1975 
This document is a scanned copy of a printed document. No warranty is given about the accuracy of the copy. Users should refer to the original published version of the material. 